\title{
Antipoliovirus Activity of the Organic Extract of Eupatorium buniifolium: Isolation of Euparin as an Active Compound
}

\author{
María Florencia Visintini Jaime, ${ }^{1}$ Rodolfo H. Campos, ${ }^{1}$ Virginia S. Martino, ${ }^{2}$ \\ Lucía V. Cavallaro, ${ }^{1}$ and Liliana V. Muschietti ${ }^{2}$ \\ ${ }^{1}$ Cátedra de Virología, Facultad de Farmacia y Bioquímica, Universidad de Buenos Aires, Junín 9564 P, 1113 Buenos Aires, Argentina \\ ${ }^{2}$ Cátedra de Farmacognosia, IQUIMEFA (UBA-CONICET), Facultad de Farmacia y Bioquímica, Universidad de Buenos Aires, \\ Junín 9562 P, 1113 Buenos Aires, Argentina
}

Correspondence should be addressed to Liliana V. Muschietti; lmusch@ffyb.uba.ar

Received 9 April 2013; Revised 11 June 2013; Accepted 13 June 2013

Academic Editor: Raffaele Capasso

Copyright @ 2013 María Florencia Visintini Jaime et al. This is an open access article distributed under the Creative Commons Attribution License, which permits unrestricted use, distribution, and reproduction in any medium, provided the original work is properly cited.

\begin{abstract}
The antiviral activity of the organic extract (OE) of Eupatorium buniifolium against poliovirus type 1 was determined by in vitro assays with an effective concentration $50\left(\mathrm{EC}_{50}\right)$ of $23.3 \pm 3.3 \mu \mathrm{g} / \mathrm{mL}$. Bioassay-guided fractionation of the $\mathrm{OE}$ allowed the isolation of an active principle that was identified by spectroscopic methods $\left({ }^{1} \mathrm{H}\right.$ - and ${ }^{13} \mathrm{C}-\mathrm{NMR}, \mathrm{EI}-\mathrm{MS}$, UV, and IR spectroscopy) as the benzofuran euparin. The plaque reduction assay in Vero cells was used to assess the antiviral activity of euparin against poliovirus types 1,2 , and 3 with $\mathrm{EC}_{50}$ values of $0.47,0.12$, and $0.15 \mu \mathrm{g} / \mathrm{mL}$, respectively. Moreover, this compound showed high selectivity indexes of 284.9, 1068, and 854.7, respectively. In order to identify the mechanism by which euparin exerts its antiviral activity, the virucidal effect, the pretreatment of Vero cells, and the time of action on one viral replication cycle were evaluated. Results obtained demonstrated that euparin exerts its effect during the early events of the replication cycle, from the virus adsorption to cells up to the first twenty minutes after infection. This is the first report on the presence of euparin in E. buniifolium and its antiviral activity.
\end{abstract}

\section{Introduction}

Poliomyelitis is caused by poliovirus (PV), which can affect the nervous system causing permanent paralysis. PV is an RNA virus that belongs to the genus Enterovirus of the large family of Picornaviridae. There are three serotypes of PV (i.e., PV-1, PV-2, and PV-3).

Two trivalent polio vaccines have been available since 1961: the intramuscular inactivated vaccine of Salk and the oral attenuated vaccine of Sabin. Both of them stimulate the production of neutralizing antibodies antipolioviruses that protect from the disease. Polioviruses have been eradicated from the United States in 1980 and from the Western Hemisphere in 1991. In 1999, the Global Polio Eradication Initiative wiped out PV-2. Nowadays, and according to the World Health Organization, poliomyelitis remains endemic in Afghanistan, Nigeria, and Pakistan and transmission has been reestablished in three countries which were previously declared as polio-free (Angola, Chad, and the Democratic Republic of the Congo) [1].

In 2006, the "Committee on Development of a Polio Antiviral and Its Potential Role in Global Poliomyelitis Eradication" highlighted the importance of the potential role of an antiviral drug in the context of polio eradication [2] that would be used: (i) for immunodeficient people who are chronically shedding poliovirus, (ii) for people exposed to poliovirus, for example, through unintentional laboratory exposure, (iii) for communities exposed to circulating vaccine-derived poliovirus outbreaks in the posteradication era (likely in conjunction with inactivated polio vaccine).

One strategy for the development of antiviral agents is the search for novel compounds from natural sources. A variety of lead molecules, mainly those isolated from higher plants, have already been reported: terpenoids, flavonoids, coumarins, alkaloids, and lignans [3-6]. Among the numerous medicinal plants growing in our country, Eupatorium 
buniifolium Hook. et Arn. (Asteraceae), popularly known as "romerillo," "romerillo Colorado," or "chilca," is traditionally used as disinfectant and against rheumatic pains $[7,8]$. It has been reported to possess in vitro anti-inflammatory [9], antioxidant [10], and trypanocidal [11] activities and that some of its extracts can inhibit Herpes simplex virus type I replication [12] and reduce Herpes suis virus viral infectivity [13].

In this study, we report the antiviral activity of the organic extract of Eupatorium buniifolium and the isolation and identification of a new antipoliovirus compound, by bioassayguided fractionation and its possible mechanisms of action.

\section{Materials and Methods}

2.1. Plant Material. The aerial parts of Eupatorium buniifolium were collected in Departamento Tafí del Valle in the province of Tucumán, Argentina, in May 2009. The plant material was identified by A. Slanis-B. Juarez and a voucher specimen (Slanis-Juarez 1043 or LIL609703) is deposited at the Herbarium of the Fundación Miguel A. Lillo, University of Tucumán, Argentina.

2.2. Extraction of Plant Material. Air-dried and ground aerial parts $(500 \mathrm{~g})$ were extracted by maceration with dichloromethane: methanol $(1: 1)$ for $24 \mathrm{~h}$ and then vacuumfiltered. The process was repeated twice and the filtrates were combined and taken to dryness under vacuum to obtain the organic extract (OE). The marc was air-dried and then extracted with water $(500 \mathrm{~mL})$ under the same conditions. The resulting aqueous extract (AE) was freeze-dried.

2.3. Bioassay-Guided Fractionation of E. buniifolium $\mathrm{CH}_{2} \mathrm{Cl}_{2}$ : $\mathrm{MeOH}(1: 1)$ Extract (OE) and Isolation of the Active Compound. The fractionation of $\mathrm{OE}(30 \mathrm{~g})$ was done by open column chromatography loaded with silicagel 60 (Merck, 0.063-0.2 mm/70-230 mesh; $300 \mathrm{~g}$ ) and eluted with a step gradient of hexane : ethylacetate $(100: 0$ to $0: 100)$ and ethylacetate: methanol $(100: 0$ to $0: 100)$. Ten fractions $(250 \mathrm{~mL})$ were obtained and monitored by thin layer chromatography (TLC), carried out on silicagel plates with hexane: ethylacetate $(1: 1)$ as mobile phase. Fractions with the same chromatographic profile were combined into five fractions $\left(\mathrm{F}_{1}-\mathrm{F}_{5}\right)$.

Fraction $\mathrm{F}_{2}(2.1 \mathrm{~g})$ was purified by column chromatography on silicagel $60(100 \mathrm{~g})$ and eluted with $100 \%$ hexane, hexane : ethylacetate $(9: 1 ; 7: 3 ; 1: 1), 100 \%$ ethylacetate, ethylacetate: methanol $(1: 1)$, and $100 \%$ methanol, obtaining 42 fractions of $15 \mathrm{~mL}$ each, that were combined afterwards into 17 subfractions $\left(\mathrm{F}_{2 . \mathrm{I}}-\mathrm{F}_{2 . \mathrm{XVII}}\right)$ according to their TLC profile. From fraction $\mathrm{F}_{2 . \mathrm{VI}}$, euparin crystallized as yellow needles. Melting point was determined in a Thomas Hoover apparatus.

2.4. Spectrometric Analyses. Euparin was identified by nuclear magnetic resonance ${ }^{1} \mathrm{H}-\mathrm{NMR}$ and ${ }^{13} \mathrm{C}-\mathrm{NMR}$ (NMR Varian Inova, $500 \mathrm{MHz}$ in $\mathrm{CDCl} 3$ ), electron impactmass spectrometry (EI-MS) (Agilent 5973), ultraviolet spectroscopy (UV) (Jasco V-630), and infrared spectroscopy (IR) (Nicolet 380 FT-IR-Smart Multi Bruce HATR, Zn Se $\left.45^{\circ}\right)$.

2.5. Cells and Viruses. Vero cells (ATCC CCL 81) were obtained from Asociación Banco Argentino de Células and cultured at $37^{\circ} \mathrm{C}$ in a $5 \% \mathrm{CO}_{2}$ incubator in growth medium: Eagle's minimal essential medium (Gibco) supplemented with $10 \%$ fetal bovine serum (FBS, PAA), $100 \mu \mathrm{g} / \mathrm{mL}$ streptomycin, $100 \mathrm{IU} / \mathrm{mL}$ penicillin, $2 \mathrm{mM}$ L-glutamine, and $100 \mu \mathrm{M}$ nonessential amino acids (Gibco). Infection Medium (IM), which was used for the antiviral assays, was the same as the growth medium but with $2 \%$ FBS. Plaque medium (PM) was IM containing $1 \%$ methylcellulose (Sigma). Poliovirus types 1, 2, and 3 (PV-1, PV-2, and PV-3) Sabin strains and herpes simplex virus type 1 (HSV-1) F strain were kindly provided by Dr. María Cecilia Freire (ANLIS-Instituto Dr. Carlos G. Malbrán, Argentina) and Dr. Albert Epstein, respectively. Vesicular stomatitis virus (VSV), Indiana strain (ATCC VR1421), was purchased from ATCC. All virus stocks were stored at $-70^{\circ} \mathrm{C}$ until used. Viral stocks were propagated and quantified in Vero cells. The number of plaque forming units per $\mathrm{mL}(\mathrm{PFU} / \mathrm{mL})$ was determined by the plaque assay for virus quantification.

2.6. Viral Cytopathic Effect Reduction Assay. Antiviral activities of E. buniifolium extracts (OE and AE) against PV-1 were performed by measuring the reduction of the viral cytopathic effect (CPE). Confluent Vero cells monolayers growing in 96well plates after $24 \mathrm{~h}$ of culture were infected with PV-1 at a multiplicity of infection (m.o.i) of $0.01 \mathrm{PFU} /$ cell in presence of both 25 and $100 \mu \mathrm{g} / \mathrm{mL}$ of OE diluted in dimethyl sulfoxide (DMSO) and AE diluted in sterile distilled water. Control viruses and mock-infected cells were included in each plate. Then, the plate was incubated $\left(37^{\circ} \mathrm{C}, 5 \% \mathrm{CO}_{2}\right)$ until $90 \%$ of viral CPE was reached at control viruses. The reduction of viral CPE was determined by assessment of cell viability by the 3-(4,5-dimethylthiazol-2-yl)-2,5-diphenyltetrazolium bromide (MTS/PMS) assay (CellTiter 96 Aqueous-Promega, Madison, WI) according to the manufacturer's instructions. The absorbance at $490 \mathrm{~nm}$ was read in an automatic plate reader (Multi-Mode Microplate Reader-SynergyTM HTBioTek) according to \% CPE reduction $=\left[\left(\mathrm{Abs}_{\text {treated }}-\right.\right.$ $\left.\left.\mathrm{Abs}_{\text {control virus }}\right) /\left(\mathrm{Abs}_{\text {cellular control }}-\mathrm{Abs}_{\text {control virus }}\right)\right] * 100$.

2.7. Cytotoxicity Assay. Cell viability was assessed by the MTS/PMS test as previously described [14]. Briefly, subconfluent monolayers of Vero cells cultures $\left(8 \times 10^{3}\right.$ cells/well; $24 \mathrm{~h}$ ) in 96-well plates were exposed to twofold dilutions of $\mathrm{OE}$, fractions $\mathrm{F}_{2}-\mathrm{F}_{4}$, and euparin in DMSO for $72 \mathrm{~h}$ at $37^{\circ} \mathrm{C}$. Cellular controls were incubated under the same conditions in presence of growth medium without drug. Cell viability was calculated as $\left[\mathrm{Abs}_{\text {treated cells }} / \mathrm{Abs}_{\text {cellular control }}\right] \times$ 100. The cytotoxic concentration $50\left(\mathrm{CC}_{50}\right)$ is defined as the concentration that reduces cell viability by $50 \%$ with respect to cell control and is determined from dose-response curves. The maximum noncytotoxic concentration (MNCC) is the 
maximum concentration of $\mathrm{OE}$, fraction, or euparin that leaves $100 \%$ of viable cells.

2.8. Plaque Reduction Assay. Confluent Vero cell monolayers seeded in 24 -well plates $\left(24 \mathrm{~h} ; 5 \% \mathrm{CO}_{2} ; 37^{\circ} \mathrm{C}\right)$ were infected with $100 \mathrm{PFU}$ of $\mathrm{PV}-1 /$ well in presence of serial twofold dilutions from the MNCC of E. buniifolium $\mathrm{OE}$, fractions $\mathrm{F}_{1}-$ $\mathrm{F}_{5}$, or euparin. Following $45 \mathrm{~min}$ of adsorption at $37^{\circ} \mathrm{C}$, the viral inoculum was removed; cell monolayers were washed twice and overlaid with PM supplemented with the same concentrations of $\mathrm{OE}$, fractions $\mathrm{F}_{1}-\mathrm{F}_{5}$ or euparin added during the adsorption period. Mock-infected cells and virus control were included. After $24-48 \mathrm{~h}$ of incubation cell monolayers were fixed and stained with $0.75 \%$ crystal violet in methanol : water $(40: 60)$ and viral plaques were counted. The effective concentration $50\left(\mathrm{EC}_{50}\right)$ value is the concentration of $\mathrm{OE}$, fraction, or euparin that reduces the number of viral plaques by $50 \%$ with respect to the viral control and was calculated by regression analysis of the dose-response curves generated with the data. Reduction of plaques (\%) was calculated as $[1-($ no. plaques treated $/$ no. plaques control virus $)] \times$ 100. The selectivity index (SI) was calculated as $\mathrm{CC}_{50} / \mathrm{EC}_{50}$. The antiviral activity of $E$. buniifolium $\mathrm{OE}$ and euparin was also determined against PV-2, PV-3, HSV-1, HSV-2, and VSV by reduction viral plaque assays in Vero cells monolayers as described earlier.

2.9. Virucidal Assay of Euparin. PV-1 $\left(1.0 \times 10^{6} \mathrm{PFU}\right)$ was incubated at room temperature (r.t.) or $37^{\circ} \mathrm{C}$ for $30 \mathrm{~min}$ in IM with or without $10 \mu \mathrm{g} / \mathrm{mL}\left(10 \mathrm{X} \mathrm{EC}_{90}\right)$ of euparin. The residual infectious virus particles were determined by viral plaque assays in Vero cell monolayers.

2.10. Effect of Vero Cell Pretreatment with Euparin. Pretreatment of Vero cells with euparin was evaluated as previously described [14]. Vero cell monolayers were seeded in 24-well plates. After $24 \mathrm{~h}\left(5 \% \mathrm{CO}_{2}\right.$ incubator, $\left.37^{\circ} \mathrm{C}\right)$, cells were washed twice with phosphate buffer saline (PBS) and treated with 1.0 and $10 \mu \mathrm{g} / \mathrm{mL}$ of euparin in IM, corresponding to $\mathrm{EC}_{90}$ and $10 \mathrm{X} \mathrm{EC}_{90}$, respectively. After $7 \mathrm{~h}$ incubation at $37^{\circ} \mathrm{C}$, the medium was removed; cell monolayers were washed three times with PBS and infected with 100 PFU/well of PV-1 in $0.1 \mathrm{~mL}$ of IM. Following $45 \mathrm{~min}$ of adsorption at $37^{\circ} \mathrm{C}$, the virus inoculum was removed and PM was added. After $24 \mathrm{~h}$, cells were fixed and stained and viral plaques were counted.

2.11. Time of Addition Assay of Euparin. To study the effect of euparin in the adsorption and post adsorption events of PV-1 in Vero cells, three different treatments at $1.0 \mu \mathrm{g} / \mathrm{mL}$ $\left(1 \mathrm{X} \mathrm{EC}_{90}\right.$ ) were evaluated: (i) only during adsorption period (Adsorption); (ii) after adsorption and until the end of the experiment (After Adsorption), and (iii) during and after the adsorption (Throughout). Briefly, Vero cell monolayers cultured in 24-well plates were precooled for $1 \mathrm{~h}$ at $4^{\circ} \mathrm{C}$. Cells were then infected with $100 \mathrm{PFU}$ of PV-1 virus/well in presence or absence of euparin and further incubated at $4^{\circ} \mathrm{C}$ for $1 \mathrm{~h}$. Cell monolayers were washed with PBS, and then
PM with or without euparin was added. After $24 \mathrm{~h}$, the viral plaques were counted.

2.12. Effect of Time Addition of Euparin on the One-Step Replication Cycle. Confluent Vero cell monolayers cultured in a 24-well plate were infected with PV-1 (m.o.i. = 5) for $1 \mathrm{~h}$ at $4^{\circ} \mathrm{C}$. Following the adsorption period, cells were washed three times, and $10 \mu \mathrm{g} / \mathrm{mL}$ of euparin was added at different hours after infection (h p.i.): $0,1,2,3,4,5,6$, and 7 or at different minutes p.i.: 0, 10, 20, 30, 40, 50, and 60. Cells were further incubated up to $8 \mathrm{~h}$. At this time, the supernatants were collected, clarified by centrifugation $\left(3,500 \times \mathrm{g}\right.$ at $\left.4^{\circ} \mathrm{C}\right)$, and the extracellular virus production was determined by viral plaque assays.

2.13. Statistical Analysis. Data are presented as means \pm SD of three independent assays. The $\mathrm{EC}_{50}$ and $\mathrm{CC}_{50}$ values were calculated using GraphPad Prism programme v. 5.01. Statistical differences between different treatments were determined using one way ANOVA with Tukey's posttest. Differences were considered significant when the $P$ value was less than 0.05 .

\section{Results}

3.1. Antiviral Activity of E. buniifolium $O E$ and $A E$ against $P V-1$. The antiviral activity of E. buniifolium $\mathrm{OE}$ and $\mathrm{AE}$ was determined against PV-1 by the viral cytopathic effect reduction assay. The results obtained showed that only OE inhibited PV-1 replication at the two concentrations tested (25 and $100 \mu \mathrm{g} / \mathrm{mL}$ ) with CPE reduction values higher than $50 \%$ (data not shown).

3.2. Bioassay Guided Fractionation of E. buniifolium OE and Structure Elucidation of Euparin. Fractionation of OE, by chromatographic techniques, yielded five fractions $\left(\mathrm{F}_{1}-\mathrm{F}_{5}\right)$ which were assayed for their in vitro anti-PV-1 activity by the plaque reduction assay (Figure 1 and Table 1). Further purification of $\mathrm{F}_{2}$ yielded subfractions $\mathrm{F}_{2 . \mathrm{I}}-\mathrm{F}_{2 \text { XVII }}$ (Figure 1). From fraction $\mathrm{F}_{2 . \mathrm{VI}}$ a major anti-PV compound $(39 \mathrm{mg}$; $130.0 \mathrm{mg} / 100 \mathrm{~g}$ dried extract) was isolated and identified as euparin (purity $>95 \%$, by High Performance Liquid Chromatography (HPLC); m.p. $120-122^{\circ} \mathrm{C}$ ) by comparison of its spectral data with the literature values (Figure 2) $[15,16]$.

3.3. Spectral Data of Euparin. Euparin presented the following spectral data: UV $\lambda_{\text {max }}(\mathrm{nm}) \mathrm{MeOH}$ : 260, 356; IR (KBr), $\nu_{\max }\left(\mathrm{cm}^{-1}\right): 3388(\mathrm{OH}), 1470$ (aromatic), $1636(\mathrm{C}=\mathrm{COR}) ;{ }^{1} \mathrm{H}$ NMR (MeOH-d4), $\delta$ (ppm): $8.18(1 \mathrm{H}, \mathrm{s}, \mathrm{H}-4) ; 6.95(1 \mathrm{H}, \mathrm{d}$, $J=0.5 \mathrm{~Hz} \mathrm{H} 3) ; 6.78$ (1H, s, H7); 5.74 (1H, m, H1la); 5.21 (1H, m, H1lb); $2.72(3 \mathrm{H}, \mathrm{s}, \mathrm{H}-14) ; 2.14(3 \mathrm{H}, \mathrm{s}, \mathrm{H}-12) .{ }^{13} \mathrm{C}$ NMR (DMSO-d6), $\delta$ (ppm): 204.60 (s, C-13), 161.24 (s, C-8), 159.49 (s, C-6), 157.64 (s, C-2), 132.45 (s, C-5), 124.27 (d, C-4), 121.91 (s, C-9), 116.79 (s, C-10), 112.23 (t, C-11), 102.54 (d, C-3), 98.24 (d, C-7), 25.59 (q, C-14), 17.85 (q, C-12); EI-MS (m/z, rel.int.) 218 (19.30), 217 (48.18), 216 (68.16) [M] $]^{+}, 203$ (2.52), 202 (16.22), 201 (100.00), 173 (26.88). 
TABLE 1: Cytotoxicity and antiviral activity of extracts, fractions, and euparin against PV-1, PV-2, and PV-3.

\begin{tabular}{|c|c|c|c|c|c|c|c|c|c|c|}
\hline & \multirow[b]{2}{*}{$\mathrm{CC}_{50}(\mu \mathrm{g} / \mathrm{mL})$} & \multicolumn{3}{|c|}{ PV-1 } & \multicolumn{3}{|c|}{ PV-2 } & \multicolumn{3}{|c|}{ PV -3} \\
\hline & & $\begin{array}{c}\mathrm{EC}_{50} \\
(\mu \mathrm{g} / \mathrm{mL})\end{array}$ & $\begin{array}{c}\mathrm{EC}_{90} \\
(\mu \mathrm{g} / \mathrm{mL})\end{array}$ & SI & $\begin{array}{c}\mathrm{EC}_{50} \\
(\mu \mathrm{g} / \mathrm{mL})\end{array}$ & $\begin{array}{c}\mathrm{EC}_{90} \\
(\mu \mathrm{g} / \mathrm{mL})\end{array}$ & SI & $\begin{array}{c}\mathrm{EC}_{50} \\
(\mu \mathrm{g} / \mathrm{mL})\end{array}$ & $\begin{array}{c}\mathrm{EC}_{90} \\
(\mu \mathrm{g} / \mathrm{mL})\end{array}$ & SI \\
\hline E. buniifolium $\mathrm{OE}$ & $114.8 \pm 1.8$ & $23.3 \pm 3.3$ & $47.2 \pm 2.8$ & 5.5 & $25.0 \pm 1.8$ & $41.5 \pm 3.4$ & 4.6 & $21.1 \pm 2.5$ & $38.8 \pm 5.7$ & 4.8 \\
\hline E. buniifolium $\mathrm{AE}$ & $>2000$ & Inactive & - & - & Inactive & - & - & Inactive & - & - \\
\hline Fraction $\mathrm{F}_{1}$ & n.d. & Inactive & - & - & n.d. & - & - & n.d. & - & - \\
\hline Fraction $\mathrm{F}_{2}$ & $254.2 \pm 1.2$ & $13.3 \pm 2.6$ & $32.6 \pm 1.4$ & 19 & n.d. & - & - & n.d. & - & - \\
\hline Fraction $\mathrm{F}_{3}$ & $140.8 \pm 2.7$ & $27.8 \pm 1.1$ & $43.3 \pm 2.4$ & 5.1 & n.d. & - & - & n.d. & - & - \\
\hline Fraction $\mathrm{F}_{4}$ & $205.1 \pm 3.4$ & $19.4 \pm 1.6$ & $27.2 \pm 0.2$ & 10.6 & n.d. & - & - & n.d. & - & - \\
\hline Fraction $\mathrm{F}_{5}$ & n.d. & Inactive & - & - & n.d. & - & - & n.d. & - & - \\
\hline Euparin & $128.2 \pm 2.2$ & $0.47 \pm 0.05$ & $1.01 \pm 0.01$ & 284.9 & $0.12 \pm 0.01$ & $0.52 \pm 0.01$ & 1068 & $0.15 \pm 0.01$ & $0.36 \pm 0.07$ & 854.7 \\
\hline
\end{tabular}

The maximal concentration tested for antiviral activity was $100 \mu \mathrm{g} / \mathrm{mL}$; the extract or fractions were considered inactive if they were unable to inhibit viral replication at this concentration.

n.d.: not determined.

$\mathrm{CC}_{50}$ : concentration that reduces cell viability by $50 \%$ with respect to cell control; $\mathrm{EC}_{50}$ : concentration that reduces the number of viral plaques by $50 \%$ with respect to the viral control; $\mathrm{EC}_{90}$ : concentration that reduces the number of viral plaques by $90 \%$ with respect to the viral control; $\mathrm{SI}=\mathrm{CC}_{50} / \mathrm{EC}_{50}$.

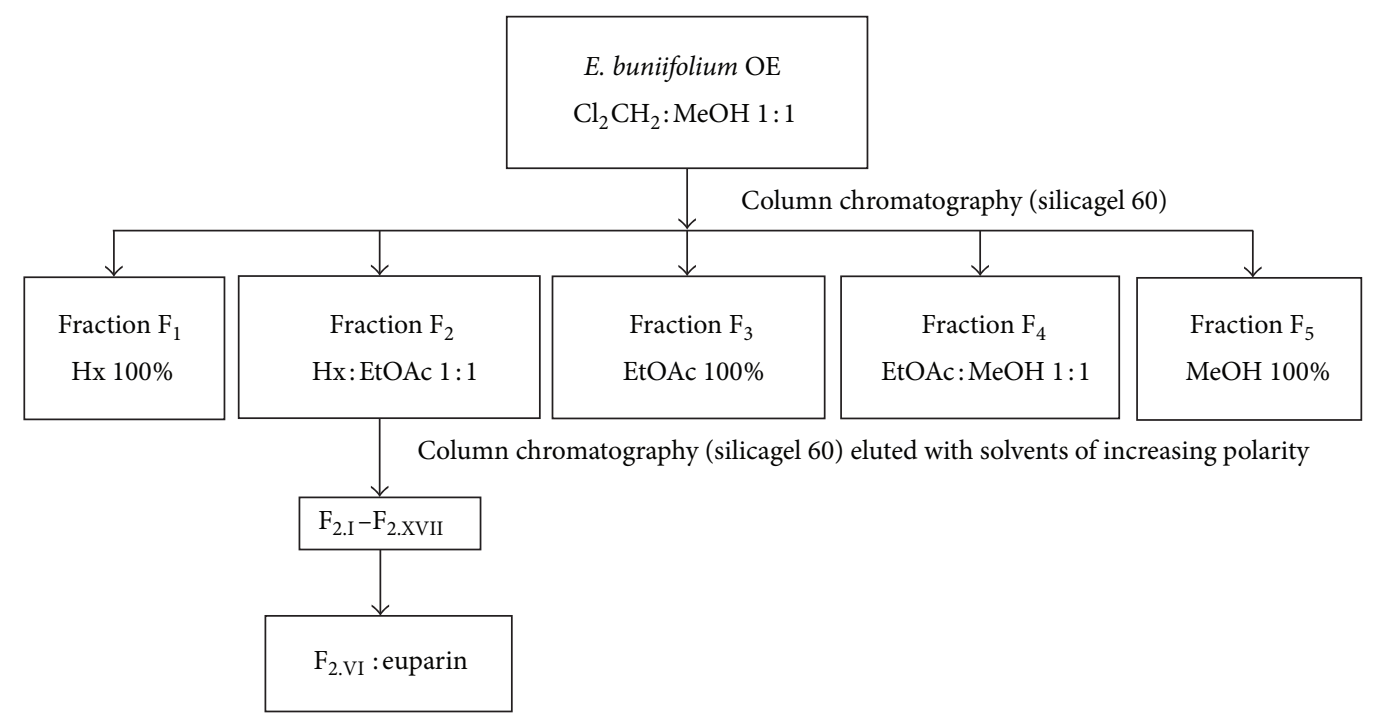

FIGURE 1: Bioassay-guided fractionation of Eupatorium buniifolium organic extract (OE).

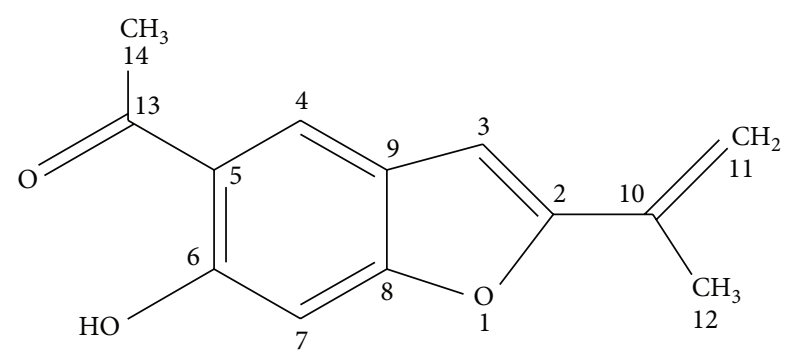

Figure 2: Chemical structure of euparin: 1-[6-hydroxy-2-(1methylethenyl)-5-benzofuranyl] ethanone, $\mathrm{C}_{13} \mathrm{H}_{12} \mathrm{O}_{3}$, MW: 216.23.

3.4. Cytotoxicity Assay. The cytotoxic effect of E. bunnifolium $\mathrm{OE}$, fraction $\mathrm{F}_{2}$ and euparin, on Vero cells, was evaluated by the MTS/PMS assay and expressed as cell viability percentage. When cells were treated with $\mathrm{OE}$, fraction $\mathrm{F}_{2}$, or euparin,
$\mathrm{CC}_{50}$ values were $114.8 \pm 1.8 \mu \mathrm{g} / \mathrm{mL}, 254.2 \pm 1.2 \mu \mathrm{g} / \mathrm{mL}$, and $128.2 \pm 2.2 \mu \mathrm{g} / \mathrm{mL}$, respectively (Table 1 ).

3.5. Antiviral Activity. The antiviral activity of E. buniifolium organic extract $(\mathrm{OE})$, fractions $\mathrm{F}_{1}-\mathrm{F}_{5}$, and euparin against PV-1 was evaluated by the plaque reduction assay. As showed in Table $1, \mathrm{EC}_{50}$ values for $\mathrm{OE}$, fraction $\mathrm{F}_{2}$, and euparin were $23.3 \pm 3.3 \mu \mathrm{g} / \mathrm{mL} ; 13.3 \pm 2.6 \mu \mathrm{g} / \mathrm{mL}$ and $0.47 \pm 0.05 \mu \mathrm{g} / \mathrm{mL}$, respectively. The SI values for $\mathrm{OE}, \mathrm{F}_{2}$, and euparin were 5.5 , 19 and 284.9 , respectively.

The antiviral activity of $\mathrm{OE}$ and euparin was also evaluated against PV-2, PV-3, HSV-1, HSV-2, and VSV by the plaque reduction assays. Results showed that $\mathrm{OE}$ was active against PV-2, and PV-3 with $\mathrm{EC}_{50}$ values of $25.0 \pm 1.8 \mu \mathrm{g} / \mathrm{mL}$ and $21.1 \pm 2.5 \mu \mathrm{g} / \mathrm{mL}$, respectively. Euparin showed $\mathrm{EC}_{50}$ values of $0.12 \pm 0.01 \mu \mathrm{g} / \mathrm{mL}(\mathrm{SI}=1068)$ and $0.15 \pm 0.01 \mu \mathrm{g} / \mathrm{mL}$ $(\mathrm{SI}=854.7)$ against PV-2 and PV-3 respectively (Table 1$)$. 
Neither E. buniifolium OE nor euparin showed antiviral activity against HSV-1, HSV-2, and VSV.

3.6. Virucidal Activity and Effect of Vero Cells Pretreatment with Euparin on PV-1 Infection. No significant reduction of viral infectivity was observed when the viruses were in direct contact (treated) with concentrations of euparin as high as $10 \mu \mathrm{g} / \mathrm{mL}\left(10 \mathrm{X} \mathrm{EC}_{90}\right)$. These results suggested that euparin did not exert a virucidal activity against PV-1 (Figure 3(a)).

Moreover, the addition of 1.0 and $10 \mu \mathrm{g} / \mathrm{mL}$ of euparin to Vero cells monolayers $7 \mathrm{~h}$ before infection with PV-1 did not exert any reduction in viral infection. Thus, it can be deduced that no antiviral activity was induced in these cells during the pretreatment with euparin (Figure 3(b)).

3.7. Time of Addition of Euparin. To determine the time of the viral cycle at which euparin interferes with viral replication, an assay was carried out by adding $1.0 \mu \mathrm{g} / \mathrm{mL}\left(1 \mathrm{X} \mathrm{EC} \mathrm{E}_{90}\right.$ ) of this compound during the different infection periods. The maximum inhibition was obtained when the compound was present in the postadsorption period or throughout the infection time (Figure 4).

3.8. Effect of Time Addition of Euparin on the One-Step Viral Replication Cycle of PV-1. The effect of addition of euparin on one cycle of virus replication was evaluated to define which step of PV-1 replication is inhibited. Euparin was added at different $h$ p.i. and then extracellular viral production was evaluated at $8 \mathrm{~h}$ p.i. Viral titers were markedly reduced when the compound was added during the first hour p.i., after which this effect was not observed, suggesting that euparin may be acting at a time point between 0 and $1 \mathrm{~h}$ p.i. (Figure 5(a)). The same experiment was repeated but adding it during the first h p.i., every $10 \mathrm{~min}$. The results (Figure 5(b)) showed that euparin is needed to be present before the first 20 min p.i. to obtain the maximal inhibitory effect.

\section{Discussion}

Throughout history, medicinal plants have been widely used to treat a great variety of diseases, and the majority of new drugs have been developed from natural products and from compounds derived from these sources. The research and development of new natural compounds with antiviral activity have attracted the researchers' interest $[17,18]$ as good candidates suitable for further modification and optimization of bioactivity.

In this context, we have evaluated the antiviral activity of the medicinal plant E. buniifolium against PV-1. Among the extracts tested, only the organic extract (OE) exerted antiviral activity $\left(\mathrm{EC}_{50}=23.3 \pm 3.3 \mu \mathrm{g} / \mathrm{mL}\right)$.

This finding prompted us to perform a bioassay-guided fractionation of $\mathrm{OE}$ by chromatographic techniques. Among all the fractions obtained $\left(\mathrm{F}_{1}-\mathrm{F}_{5}\right), \mathrm{F}_{2}$ showed the highest antiviral activity $\left(\mathrm{EC}_{50}=13.3 \pm 2.6 \mu \mathrm{g} / \mathrm{mL}\right)$ and was selected for further purification. From this fraction a bioactive compound was isolated and identified as the benzofuran euparin $\left(\mathrm{EC}_{50}=0.47 \pm 0.05 \mu \mathrm{g} / \mathrm{mL}\right)$. The $\mathrm{EC}_{50}$ values obtained for

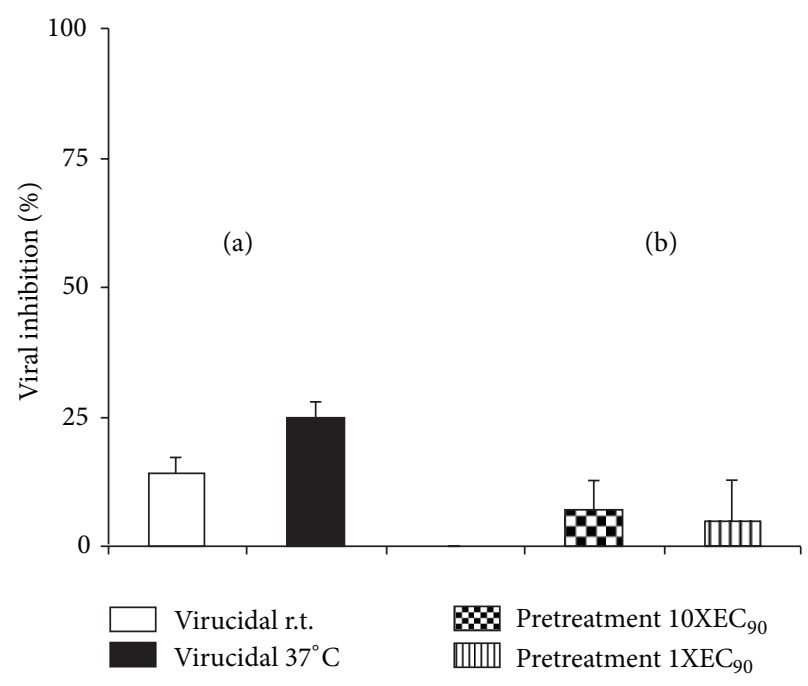

FIGURE 3: Virucidal activity (a) and the effect of pretreatment of Vero cells with euparin (b). The virucidal activity of $10 \mu \mathrm{g} / \mathrm{mL}(10 X$ $\left.\mathrm{EC}_{90}\right)$ at $37^{\circ} \mathrm{C}$ and r.t. and the pretreatment with 1.0 and $10 \mu \mathrm{g} / \mathrm{mL}$ were evaluated against PV-1. Data represent \% of virus inhibition compared to untreated controls as mean $\pm \mathrm{SD}(n=3)$. Experiments were done in quadruplicate.

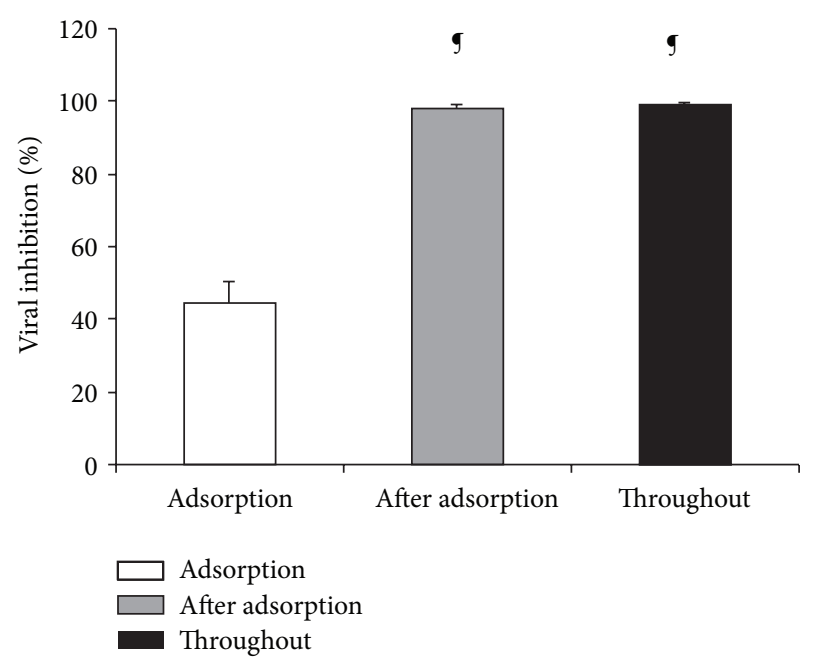

Figure 4: Percentage of viral inhibition against PV-1 under different experimental conditions. Euparin $(1.0 \mu \mathrm{g} / \mathrm{mL})$ was present at the indicated times. Data represents \% of virus inhibition obtained at each condition with respect to untreated control as mean \pm SD $(n=3)$. Experiments were done in quadruplicate. ${ }^{\text {g }} P<0.001$ versus Adsorption.

$\mathrm{OE}$, fraction $\mathrm{F}_{2}$, and euparin demonstrated that a progressive increase in the anti PV-1 activity was gained during the purification process.

Euparin was first isolated from Eupatorium purpureum [19] and its chemical structure was defined as a benzofuran by Kamthong and Robertson in 1939 [20]. 


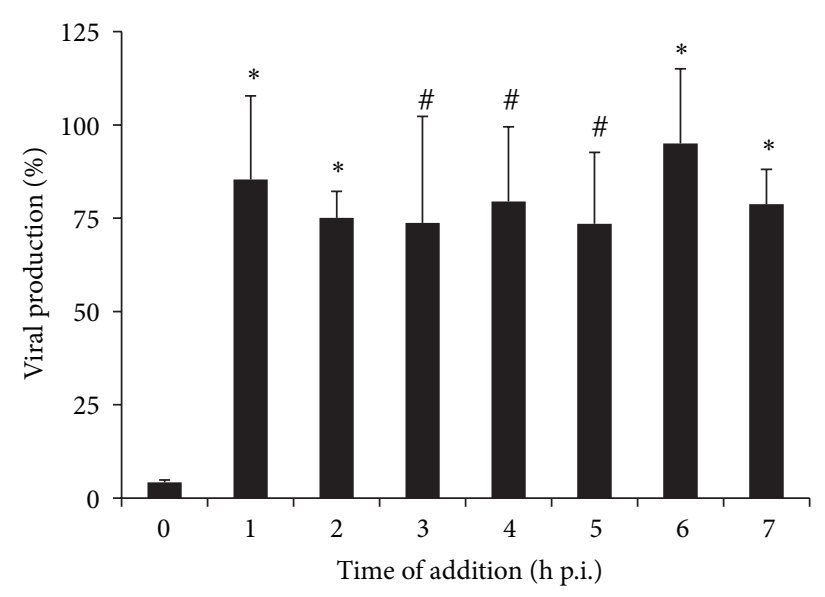

(a)

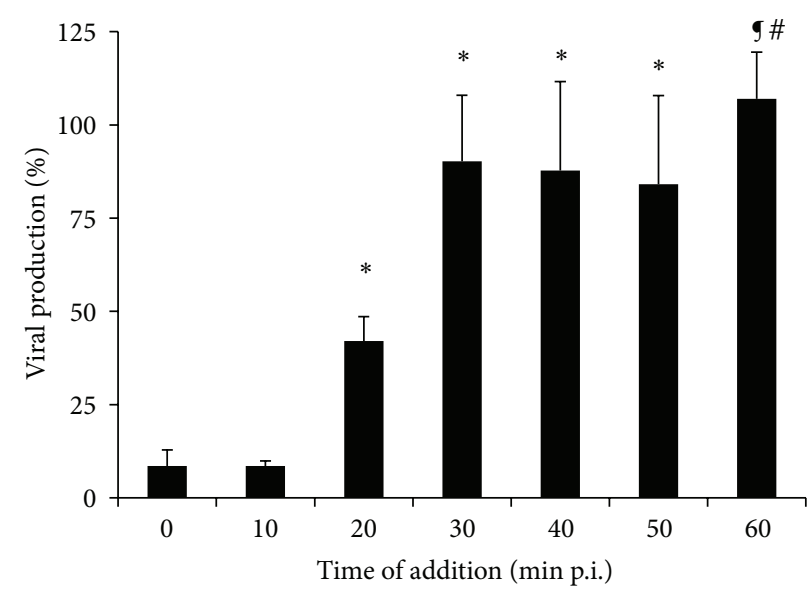

(b)

FIGURE 5: Effect of addition of euparin on the PV-1 production during a one-step replication cycle. Vero cell monolayers were infected at m.o.i. $=5$ and euparin $(10 \mu \mathrm{g} / \mathrm{mL})$ was added at different $\mathrm{h}$ p.i. (a) or min p.i. (b), after the adsorption period. At $8 \mathrm{~h}$ p.i. at $37^{\circ} \mathrm{C}$, the extracellular PV-1 production was determined by the viral plaque assay. ${ }^{*} \mathrm{P}<0.01$ versus $0 \mathrm{~h}$ p.i.; versus 0 min p.i.; versus 10 min p.i. ${ }^{\#} P<0.05$ versus $0 \mathrm{~h}$ p.i.; versus 0 min p.i. ' $P<0.001$ versus 0 min p.i.; 10 min p.i.

Natural benzofurans are heterocyclic compounds frequently synthesized by species of the Asteraceae family. Benzofurans and their derivatives show a wide range of pharmacological properties such as antiviral, antimicrobial, antifungal, anti-inflammatory, antiallergic, and cytotoxic activities [21-27]. Although many biological assays employing euparin have been undertaken, only a few pharmacological activities have been demonstrated [28, 29]. However, its antiviral activity had not been evaluated so far.

Euparin showed low cytotoxicity on Vero cells while exerting a significant antiviral activity against the three types of polioviruses (PV-1, PV-2, and PV-3), and consequently high selectivity has been demonstrated with SI values of $284.9,1068$, and 854.7 , respectively.

These results prompted us to characterize the probable mechanism of action. As euparin showed neither virucidal activity nor protection of the cells in the pretreatment, we decided to evaluate which step of viral cycle was inhibited by this compound.

Time of addition assays demonstrated that euparin completely inhibited the viral plaques formation when it was added in the postadsorption period. This result was later confirmed with time of addition assay on one-step replication viral cycle where we observed that the maximum inhibition was obtained when euparin was added during the first twenty minutes after infection. This inhibition was abolished when euparin was added beyond that time. These results suggest that the likely euparin mechanism of action would be the interference with one of the first events of poliovirus replication cycle probably on the penetration and/or uncoating process and not the viral RNA replication step. We could speculate that euparin exert a similar mechanism of action as other antiviral compounds called capsid binders as the WIN compounds [30]. Euparin, as well as these compounds (i.e., V-073), could bind at the innermost end of the hydrophobic pocket within VP1 [24], but it does not prevent attachment of the virus to the host cell, leading to a more rigid capsid making the virus more resistant to uncoating, thus preventing the RNA delivery to the cellular cytoplasm. Further studies are necessary to properly define the mechanism of action of euparin.

In addition, the high selectivity activity against poliovirus in the submicromolar order, specially PV-1, and the specificity of euparin among the evaluated viruses make this an interesting compound for the development of new antipoliovirus drugs since many prototype drugs under clinical trials, as pleconaril, are unable to inhibit PV-1 [31].

\section{Conclusions}

In this study we report the antipoliovirus activity of Eupatorium buniifolium and the isolation of euparin, as the active principle responsible for this activity. The results obtained contribute to describe a new biological activity in a known compound and suggest that euparin emerges as a new selective antipoliovirus drug or as a lead molecule for the developing of more potent derivatives. To our knowledge, this is the first report describing the presence of euparin in $E$. buniifolium and also the first detection of its antiviral activity. Further studies are being undertaken to define the molecular target of euparin.

\section{Conflict of Interests}

None of the authors have disclosed any conflict of interests.

\section{Authors' Contribution}

Lucía V. Cavallaro and Liliana V. Muschietti contributed equally to this paper. 


\section{Acknowledgments}

This work was supported by Grants from Consejo Nacional de Investigaciones Científicas y Técnicas (CONICET) (PIP 1540 and PIP 112-200801-01169) and Universidad de Buenos Aires (UBACYT 2008-2010: B033, B045, UBACYT 20112014: 20020100100612, and UBACYT 2011-2014: 20020100100 20).

\section{References}

[1] World Health Organization, Poliomyelitis, Fact sheet no. 114, WHO, Geneva, Switzerland, 2012, http://www.who.int/mediacentre/factsheets/fs114/en/.

[2] National Research Council (U.S.). Committee on Development of a Polio Antiviral and Its Potential Role in Global Poliomyelitis Eradication, Exploring the Role of Antiviral Drugs in the Eradication of Polio. Workshop Report, National Academies Press, 2006.

[3] T. Creagh, J. L. Ruckle, D. T. Tolbert et al., "Safety and pharmacokinetics of single doses of (+)-calanolide A, a novel, naturally occurring nonnucleoside reverse transcriptase inhibitor, in healthy, human immunodeficiency virus-negative human subjects," Antimicrobial Agents and Chemotherapy, vol. 45, no. 5, pp. 1379-1386, 2001.

[4] Y. Kashiwada, F. Hashimoto, L. M. Cosentino, C.-H. Chen, P. E. Garrett, and K. H. Lee, "Betulinic acid and dihydrobetulinic acid derivatives as potent anti-HIV agents," Journal of Medicinal Chemistry, vol. 39, no. 5, pp. 1016-1017, 1996.

[5] M. T. H. Khan, A. Ather, K. D. Thompson, and R. Gambari, "Extracts and molecules from medicinal plants against herpes simplex viruses," Antiviral Research, vol. 67, no. 2, pp. 107-119, 2005, Erratum in Antiviral Research, vol. 67, no. 3, p. 169, 2005.

[6] K. Kitazato, Y. Wang, and K. Nobayashi, "Viral infectious disease and natural products with antiviral activity," Drug Discovery \& Therapeutics, vol. 1, no. 1, pp. 14-22, 2007.

[7] N. Rojas Acosta, Plantas Medicinales de Corrientes, Gadola, Buenos Aires, Argentina, 1905.

[8] C. Villafuerte, Diccionario de Árboles, Arbustos y Yuyos en el Folklore Argentino, Plusultra, Buenos Aires, Argentina, 1984.

[9] L. Muschietti, S. Gorzalczany, G. Ferraro, C. Acevedo, and V. Martino, "Phenolic compounds with anti-inflammatory activity from Eupatorium buniifolium," Planta Medica, vol. 67, no. 8, pp. 743-744, 2001.

[10] M. Paya, J. Coussio, G. Ferraro et al., "Inhibitory effects of various extracts of Argentine species on free radical-mediated reactions and human neutrophil functions," Phytotherapy Research, vol. 10, no. 3, pp. 228-232, 1996.

[11] V. P. Sülsen, S. I. Cazorla, F. M. Frank et al., "Trypanocidal and leishmanicidal activities of flavonoids from Argentine medicinal plants," American Journal of Tropical Medicine and Hygiene, vol. 77, no. 4, pp. 654-659, 2007.

[12] G. H. García, R. Campos, R. A. de Torres et al., "Antiherpetic activity of some Argentine medicinal plants," Fitoterapia, vol. 61, no. 6, pp. 542-546, 1990.

[13] S. M. Zanón, F. S. Ceriatti, M. Rovera, L. J. Sabini, and B. A. Ramos, "Search for antiviral activity of certain medicinal plants from Córdoba, Argentina," Revista Latinoamericana de Microbiologia, vol. 41, no. 2, pp. 59-62, 1999.

[14] L. M. Finkielsztein, E. F. Castro, L. E. Fabián et al., "New 1indanone thiosemicarbazone derivatives active against BVDV,"
European Journal of Medicinal Chemistry, vol. 43, no. 8, pp. 1767-1773, 2008.

[15] P. Proksch and E. Rodriguez, "Chromenes and benzofurans of the asteraceae, their chemistry and biological significance," Phytochemistry, vol. 22, no. 11, pp. 2335-2348, 1983.

[16] R. Siebertz, P. Proksch, V. Wray, and L. Witte, "Accumulation and biosynthesis of benzofurans in root cultures of Eupatorium cannabinum," Phytochemistry, vol. 28, no. 3, pp. 789-793, 1989.

[17] T. Arakawa, H. Yamasaki, K. Ikeda, D. Ejima, T. Naoto, and A. H. Koyama, "Antiviral and virucidal activities of natural products," Current Medicinal Chemistry, vol. 16, no. 20, pp. 2485-2497, 2009.

[18] Y.-W. Chin, M. J. Balunas, H. B. Chai, and A. D. Kinghorn, "Drug discovery from natural sources," AAPS Journal, vol. 8, no. 2, pp. E239-E253, 2006.

[19] B. Kamthong and A. Robertson, "196. Furano-compoundspart III: euparin," Journal of the Chemical Society, pp. 925-930, 1939.

[20] B. Kamthong and A. Robertson, "198. Furano-compoundspart V: the synthesis of tetrahydroeuparin and the structure of euparin," Journal of the Chemical Society, pp. 933-936, 1939.

[21] D. S. C. Black and R. Rezaie, "Modified Vilsmeier reactions of activated benzofurans with indolines: synthesis of benzofuranfused benzocarbazoles," Tetrahedron Letters, vol. 40, no. 22, pp. 4251-4254, 1999.

[22] D. Engelmeier, F. Hadacek, T. Pacher, S. Vajrodaya, and H. Greger, "Cyclopenta[b]benzofurans from Aglaia species with pronounced antifungal activity against rice blast fungus (Pyricularia grisea)," Journal of Agricultural and Food Chemistry, vol. 48, no. 4, pp. 1400-1404, 2000.

[23] A. Gratz, U. Kuckländer, R. Bollig, C. Götz, and J. Jose, "Identification of novel CK2 inhibitors with a benzofuran scaffold by novel non-radiometric in vitro assays," Molecular and Cellular Biochemistry, vol. 356, no. 1-2, pp. 83-90, 2011.

[24] C. K. Lau, P. C. Bélanger, C. Dufresne et al., "Development of 2,3-dihydro-6-(3-phenoxypropyl)-2-(2-phenylethyl)5-benzofuranol (L-670,630) as a potent and orally active inhibitor of 5-lipoxygenase," Journal of Medicinal Chemistry, vol. 35, no. 7, pp. 1299-1318, 1992.

[25] M. Y. Rios, A. B. Aguilar-Guadarrama, and V. Navarro, "Two new benzofuranes from Eupatorium aschenbornianum and their antimicrobial activity," Planta Medica, vol. 69, no. 10, pp. 967-970, 2003, Erratum in Planta Medica, vol. 70, no. 4, p. 384, 2004.

[26] T.-W. Tsai, E.-C. Wang, S.-R. Li et al., "A new synthesis of benzofurans from phenols via claisen rearrangement and ringclosing metathesis," Journal of the Chinese Chemical Society, vol. 51, no. 6, pp. 1307-1318, 2004.

[27] S.-F. Wu, F.-R. Chang, S.-Y. Wang et al., "Anti-inflammatory and cytotoxic neoflavonoids and benzofurans from Pterocarpus santalinus," Journal of Natural Products, vol. 74, no. 5, pp. 989996, 2011.

[28] M. Mohammadi, M. Yousefi, Z. Habibi, and D. Dastan, "Chemical composition and antioxidant activity of the essential oil of aerial parts of Petasites albus from Iran: a good natural source of euparin," Natural Product Research, vol. 26, no. 4, pp. 291-297, 2012.

[29] P. Castañeda, R. Mata, and B. Lotina-Hennsen, "Effect of encecalin, euparin and demethylencecalin on thylakoid electron transport and photophosphorylation in isolated spinach chloroplasts," Journal of the Science of Food and Agriculture, vol. 78, no. 1, pp. 102-108, 1998. 
[30] A. Garozzo, A. Stivala, G. Tempera, and A. Castro, "Antipoliovirus activity and mechanism of action of 3-methylthio-5phenyl-4-isothiazolecarbonitrile," Antiviral Research, vol. 88, no. 3, pp. 325-328, 2010.

[31] A. M. de Palma, G. Pürstinger, E. Wimmer et al., "Potential use of antiviral agents in polio eradication. Emerging infectious diseases," CDC, vol. 14, no. 4, 2008. 


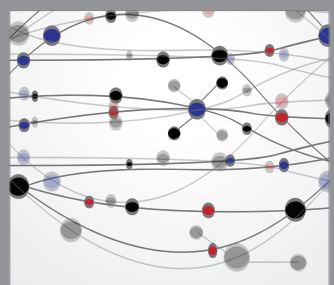

The Scientific World Journal
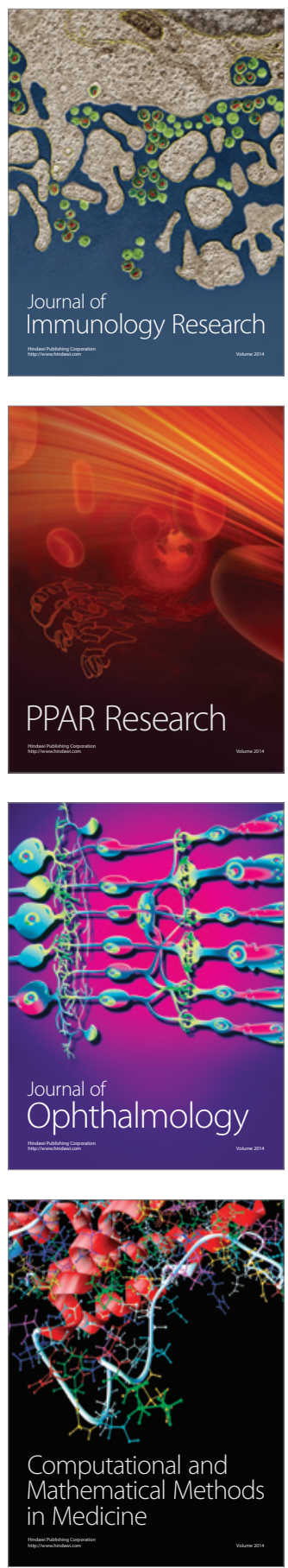

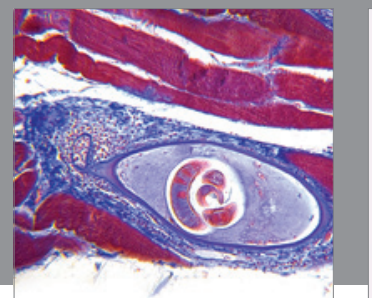

Gastroenterology

Research and Practice
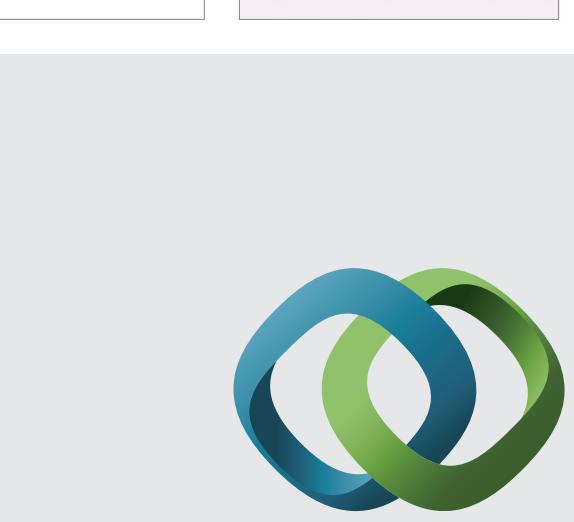

\section{Hindawi}

Submit your manuscripts at

http://www.hindawi.com
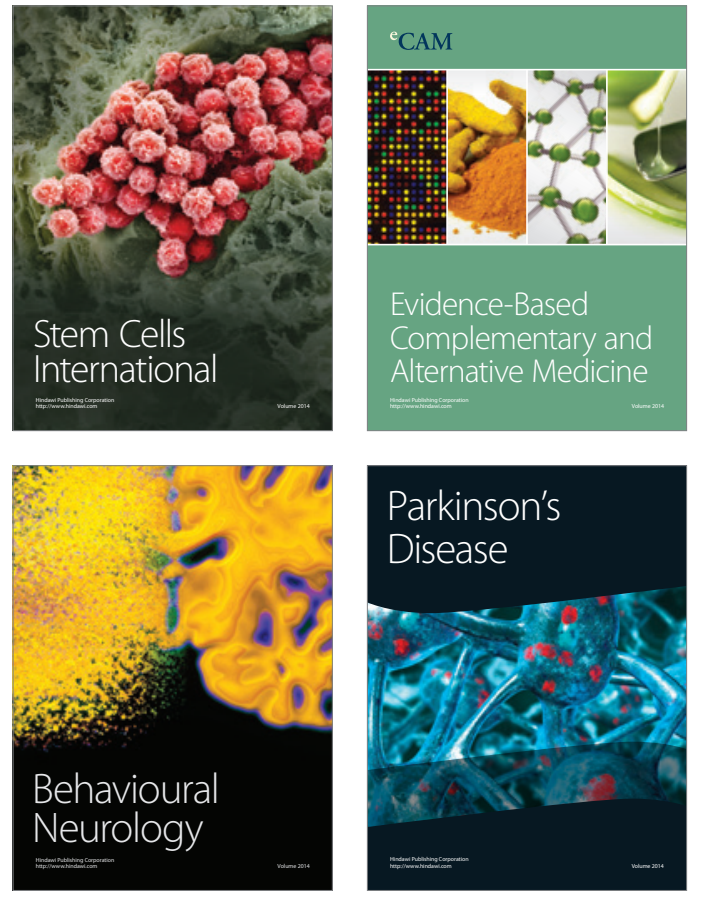
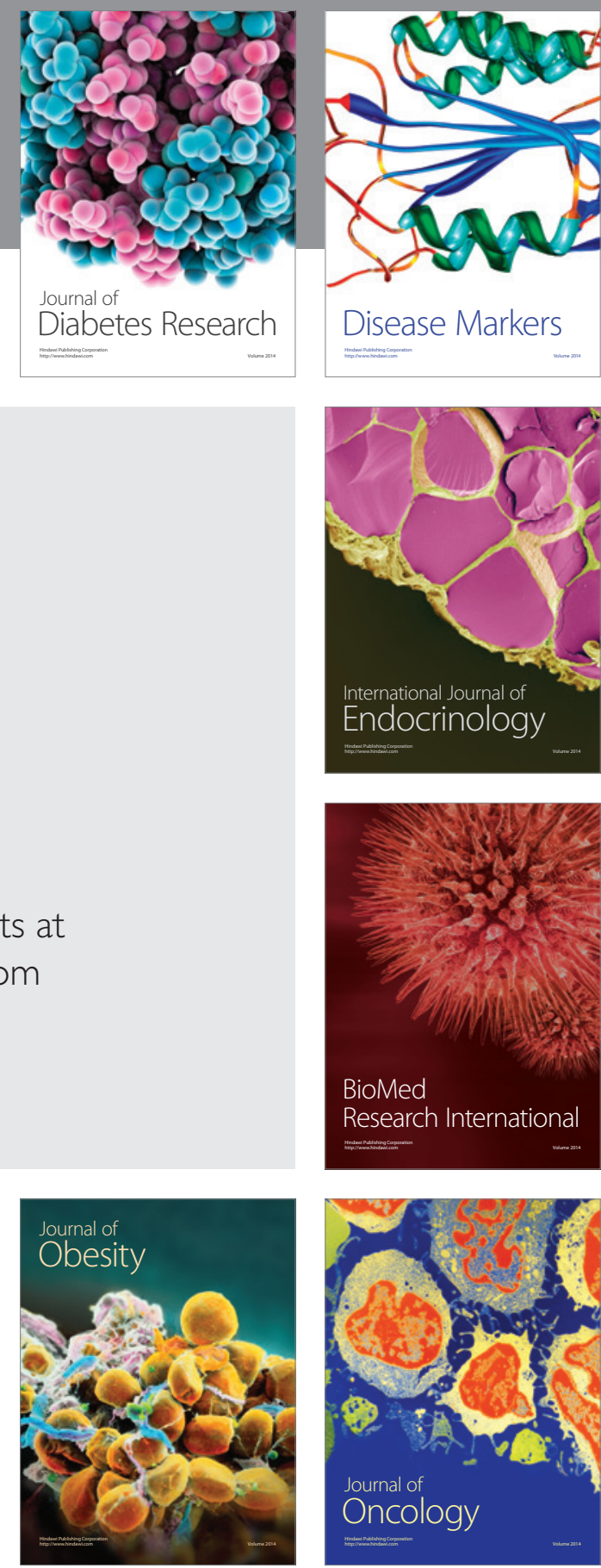

Disease Markers
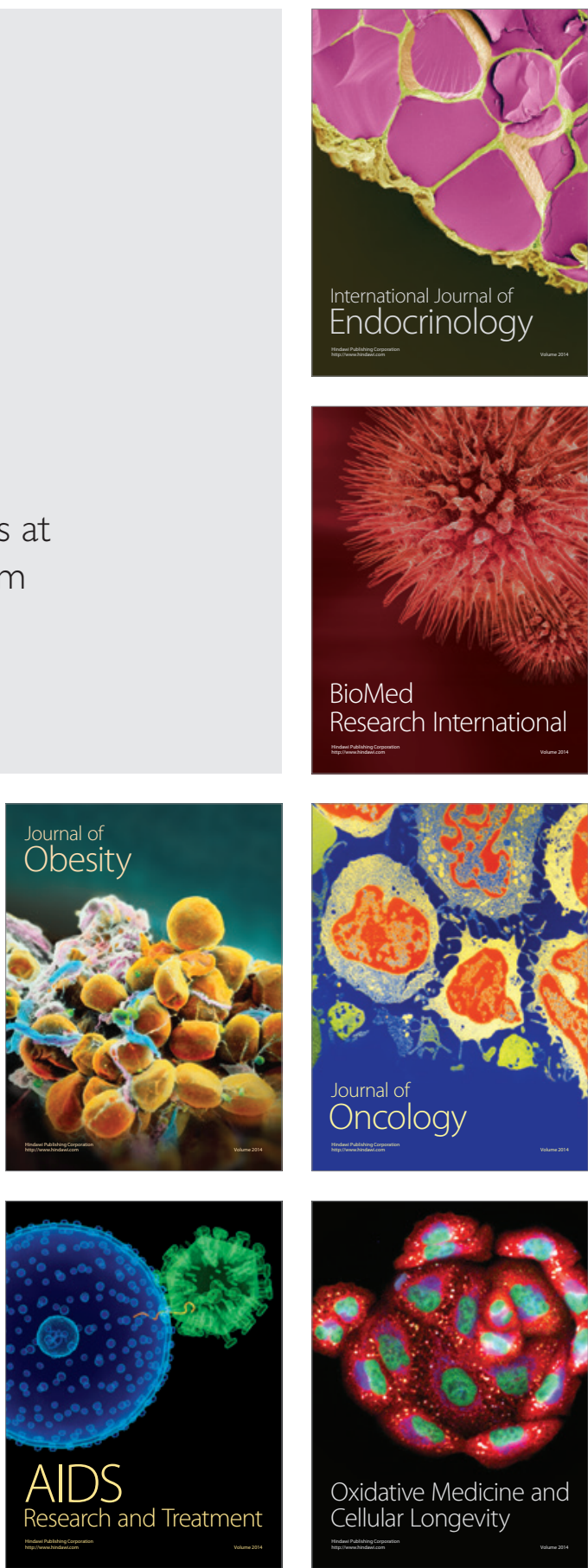